\title{
CONTEMPORARY ISSUES REGARDING MEMBER STATE LIABILITY FOR INFRINGEMENTS OF EU LAW BY NATIONAL COURTS
}

\author{
Armando Demark, PhD Candidate \\ University of Rijeka, Faculty of Law \\ Hahlić 6, 51000, Rijeka, Croatia \\ ademark@pravri.hr
}

\begin{abstract}
The objective of the paper is the analysis of the development of the concept of liability of Member States of the European union for infringements of EU law committed by national courts of last instance. Focus is placed on the improvements in the Court of Justice of the European union's (CJEU) case-law which have been made on the subject in the almost 25 years since its landmark judgment in the joined cases of Brasserie du Pêcheur and Factortame, where it was firstly explicitly stated that a Member State may be held liable for damage arising even from decisions of the judiciary. Balancing on the thin line between the doctrine of judicial independence and the need for compensation of damages suffered by a judicial breach has always been an uncomfortable and arduous legal task, which is why the CJEU occasionally undertook to clarify and improve its position on the topic during the twenty first century.

Even though serious advancement towards satisfying both of the aforementioned notions have been carried out by the CJEU in almost a quarter of a century since the Brasserie judgment, many legal predicaments and insufficiently answered questions which may arise in modern cases still remain present. The paper in its introductory part addresses the impact of the Francovich and Brasserie judgments which are considered landmark rulings in the area of Member State liability. In the central part, it demonstrates the more in-depth standpoint of the CJEU in the area of Member State liability for infringements committed within judicial decisions that firstly appeared in the CJEU's Köbler judgment. Furthermore, it depicts how the CJEU further interpreted the criteria required for Member State liability for infringements of EU law by national courts to arise. The focal point of the paper deals with the most recent case-law of the CJEU that demonstrates how it attempts to tackle the issues around Member State liability in contemporary times. Since not everyone seems to be in full agreement with the current Member State liability arrangements in that regard, certain disagreements of legal scholarship with the CJEU's latest solutions are also discussed. Finally, as a conclusion, a step-by-step demonstration of the obstacles which injured persons face in an action for damages suffered by a breach
\end{abstract}


of EU law caused by a judicial decision of a national court of last instance is provided, and suggestions for future improvements and developments in this legal area are also pointed out.

Keywords: Member State liability, CJEU, manifest infringement, sufficiently serious breach

\section{INTRODUCTION - SETTING THE SCENE FOR A MEMBER STATE LIABILITY FRAMEWORK FOR DECISIONS OF NATIONAL COURTS CONTRARY TO EU LAW}

The necessity of the existence of a legal framework for non-contractual liability of Member States for infringements of EU law has never truly been a matter of extreme dispute. It should be noted that it is true that the Treaty on the Functioning of the European Union deals exclusively with infringements committed by the EU itself, as well as its institutions and servants, ${ }^{1}$ but that there are no written rules about the liability of Member States in that regard, let alone their national courts. Even in the earliest days of paving the way for the introduction of a Member States' liability framework, it could be seen that an emphasis would be placed on constructing a systematic case-law regime with regard to this matter, i.e. that the Court of Justice of the European Union (hereinafter: CJEU) would play the main role in making sure that the Member States are abiding by EU law. ${ }^{2}$ Indeed, from the very beginning the judicial thinking of the CJEU was in favour of establishing solid legal grounds for such liability. ${ }^{3}$ For instance, it was already in the Humblet case that the Court pointed out the obligation of a Member State to make reparation for unlawful consequences stemming from a measure that the CJEU determined contrary to EU law, ${ }^{4}$ namely, to Article 86 of the Coal and Steel Community Treaty. ${ }^{5}$

Although the CJEU was enhancing its viewpoint on Member State liability throughout the following period, ${ }^{6}$ there were also instances within it when it took a different opinion, such as the one in Rewe $v$ Hauptzollamt Kiel, where it decided that the EC Treaty ${ }^{7}$ was not intended to create new remedies. ${ }^{8}$ It required thirty

1 Treaty on the Functioning of the European Union (TFEU), OJ C 326, 26 October 2012, (consolidated version), Article 340 para. 2 and 3

2 Rodríguez, P. M., State Liability for Judicial Acts in European Community Law: The Conceptual Weaknesses of the Functional Approach, The Columbia Journal of European Law, vol. 11, no. 3, 2005, pp. 605-621, p. 606

3 Biondi, A.; Farley, M., The Right to Damages in European Law, Wolters Kluwer, 2009, p. 11

4 Case C-6/60 Humblet v Belgium [1960] ECR English special edition 559, at 569

5 Treaty Establishing The European Coal and Steel Community of 18 April 1951

6 See e.g. Case C-60/75 Russo v AIMA [1976] ECR 45, par. 9

7 Treaty establishing the European Community, OJ C 325, 24.12.2002, p. 33-184 (consolidated version)

$8 \quad$ Case C-158/80 Rewe-Handelsgesellschaft Nord mbH and Rewe-Markt Steffen v Hauptzollamt Kiel [1981] ECR 1805, par. 44 
years, until the Francovich case appeared before the CJEU, for it to adamantly ascertain that "...it is a principle of Community law that the Member States are obliged to make good loss and damage caused to individuals by breaches of Community law for which they can be held responsible. "The final settlement of the aforementioned debate may be attributed not only to the ubi ius, ibi remedium principle, according to which it is the available remedies that determine the value of a right, but also to the change in the legal and political climate of that time. ${ }^{10}$

In any event, the Court in Francovich laid down the then applicable three main conditions which needed to be fulfilled for Member State liability to arise: (i) the directive should grant rights to individuals, (ii) the content of those rights must be identifiable on the basis of the directive's provisions and (iii) there must be a causal link between the State's obligation and the loss and damage that the injured persons suffered. ${ }^{11}$ However, Francovich specifically pertained to cases in which the damage suffered was due to non-implementation of a directive and it remained unclear whether the same conditions would apply in other cases, for example, when a directive's implementation has been deficient, ${ }^{12}$ or there has been an infringement of EU law with regard to a provision with direct effect. ${ }^{13}$ Even the dominant scholarly opinion of that time still deemed it unthinkable that in accordance with Francovich, Member States' liability may be invoked for judicial acts contrary to EU law. ${ }^{14}$

Five years after Francovich, the renowned Brasserie judgment ${ }^{15}$ was reached by the CJEU. Although the factual background of the joined cases relates to damage caused by a legislative, and not a judicial act which infringed EU law, ${ }^{16}$ the

$9 \quad$ Joined cases C-6/90 and C-9/90 Francovich and Bonifaci et al. v Italy [1991] ECR I-5357, par. 37

10 Tridimas notices how the Commission wanted to provide for adeqaute remedies for non-implementation of directives in order to alleviate the process of completion of the internal market. See: Tridimas, T., The General Principles of EC Law, Oxford University Press, 1999, p. 323-324

11 Joined cases C-6/90 and C-9/90 Francovich and Bonifaci et al. v Italy [1991] ECR I-5357, par. 40

12 See e.g. Case C-392/93 The Queen and H.M. Treasury, exparte: British Telecommunications [1996] ECR I-1631, par. 45

13 See infra, note 15 , p. 3

14 Authors at that time placed priority in that regard to the need for protection of judicial independence and fostering a spirit of cooperation in national judges in matters concerning EU law. See: Steiner, J., From Direct Effects to Francovich: Shifting Means of Enforcement of Community Law, European Law Review, vol. 18, no. 1, 1993, pp. 3-22, p. 11

15 Joined cases C-46/93 and C-48/93 Brasserie du Pêcheur SA v Bundesrepublik Deutschland and The Queen $v$ Secretary of State for Transport, ex parte: Factortame Ltd and others [1996] ECR I-1029 (hereinafter: Joined cases C- $46 / 93$ and C-48/93 - Brasserie)

16 By now, the facts of these joined cases are widely known in legal scholarship. In essence, Brasserie $d u$ Pêcheur was a French beer brewer on whom Germany imposed restrictions on selling beer on its territory due to the fact that the beer did not meet German beer purity criteria, which practice was contrary 
judgment is especially noteworthy due to its introduction of substantive conditions of liability, which are continually being applied even in contemporary cases regarding judicial breaches. The CJEU therefore successfully attempted to clarify the mere rudimentary vision of these conditions set forth in Francovich ${ }^{17}$ and at the same time set out to "bridge the unbridgeable" non-contractual liability of the Union and the Member States for breaches of EU law. ${ }^{18}$

According to the opinion of the CJEU established for the first time in Brasserie, when individuals suffer a loss or damage due to an infringement of EU law by a Member State, the Member State may be held liable if the three following conditions are met: (i) the infringed rule of EU law is intended to confer rights upon individuals, (ii) the breach is sufficiently serious and (iii) there must be a direct causal link between the breach and the damage suffered. ${ }^{19}$ The aforementioned conditions, which must also be satisfied nowadays for liability to be invoked, have in case-law always been the subject of meticulous analysis. With regard to the first condition, The CJEU will in every particular case focus on the rule in question, interpreting it from a teleological standpoint, rather than strictly analysing its form or wording. ${ }^{20}$ On the other hand, the matter of causation is most often left to the national courts to deal with. ${ }^{21}$ Without a doubt, it was the condition of a sufficiently serious breach that was considered to be the broadest and hence required further explanation from the CJEU. It already in Brasserie pointed out an open number of circumstances which should be taken into account when determining whether a breach was sufficiently serious. ${ }^{22}$

to EU law according to Brasserie. On the other hand, in the Factortame case, Spanish fishermen were prohibited from registering their boats in The United Kingdom due to a Parliamentary Act which was determined by the CJEU to be contrary to EU law, after which they brought an action for damages against the British Government for sustained losses

17 Rebhahn, R., Non-Contractual Liability in Damages of Member States for Breach of Community Law, in: Koziol, H.; Schulze, R. (eds.), Tort Law of the European Community, Springer, 2008, p. 181

18 Van Gerven, W., Bridging the Unbridgeable: Community and National Tort Laws after Francovich and Brasserie, International \& Comparative Law Quarterly, vol. 45, no. 3, 1996, pp. 507-544, p. 507. See also: Brüggemeier, G., Tort Law in the European Union, Wolters Kluwer, 2015, p. 106

19 Joined cases C-46/93 and C-48/93 - Brasserie, par. 74

20 Dam, C. van, European Tort Law, Second Edition, Oxford University Press, 2013, p. 290

${ }^{21}$ For a more detailed discussion of the problem of establishing a direct causal link, see infra, chapter 3.3.

22 These factors include but are not limited to "...the clarity and precision of the rule breached, the measure of discretion left by that rule to the national or Community authorities, whether the infringement and the damage caused was intentional or involuntary, whether any error of law was excusable or inexcusable, the fact that the position taken by a Community institution may have contributed towards the omission, and the adoption or retention of national measures or practices contrary to Community law." - Joined cases C-46/93 and C-48/93 - Brasserie, par. 56 
When it comes to liability for judicial breaches, these circumstances became even more important after Bergaderm, where the CJEU decided that the determination of a breach will rely on them in cases in which the Member State had a wide margin of discretion, as is the case with any judicial decision. ${ }^{2324}$ And it should be noted that in Brasserie the Court explicitly mentioned the possibility that infringements of EU law may be attributed even to the judiciary, since all State authorities, including the national courts, must comply with EU law with which individuals' rights are regulated. ${ }^{25}$

This paper will therefore attempt to, among else, demonstrate how the legal thinking of primarily the CJEU, and consequently legal theory, developed throughout the years, from the point of outright refusing the notion of liability for judicial acts which are not in accordance with EU law, to providing for the possibility of holding national courts of highest instance liable for such infringements. Firstly, the importance of the Köbler case ${ }^{26}$ which introduced for the first time the Member State liability framework for judicial decisions of national supreme courts contrary to EU law is analyzed in the following chapter. The third chapter will then provide an overview of CJEU's most recent case law on the subject which has not yet been discussed by legal scholars to a satisfactory extent, pointing out the theoretical and practical problems which unavoidably appear within the subject Member State liability framework, accompanied by a discussion of the impact that the latest developments could potentially have in national legal systems.

\section{2. - THE KÖBLER JUDGMENT - EXPLICIT ACKNOWLEGDMENT OF MEMBER STATE LIABILITY FOR JUDICIAL DECISIONS INFRINGING EU LAW}

The aforementioned opinion for the first time received absolute confirmation in the Köbler case, where the CJEU explicitly acknowledged that the effectiveness of EU rules conferring rights to individuals would be jeopardized if individuals

23 Case C-352/98 P Laboratoires Pharmaceutiques Bergaderm SA and Jean-Jacques Goupil v Commission [2000] ECR I-5291, par. 66

24 A breach of EU law may also be automatically considered sufficiently serious if it has persisted despite a judgment establishing the existence of that breach, or the Court's settled case-law that determined the breach to be as such. See: Joined cases C-46/93 and C-48/93 - Brasserie, par. 57; See also: Alto, P., Twelve Years of Francovich in the European Court of Justice: A Survey of the Case-law on the Interpretation of the Three Conditions of Liability, in: Moreira de Sousa, S.; Heusel, W. (eds.), Enforcing Community Law from Francovich to Köbler: Twelve Years of the State Liability Principle, Academy of European Law, vol. 37, 2004, pp. 59-77, p. 70-71

25 Joined cases C-46/93 and C-48/93 - Brasserie, para. 34

26 Case C-224/01 Gerhard Köblerv Republik Österreich [2003] ECR-I-10239 (hereinafter: Case C-224/01 -Köbler) 
would be unable to obtain reparation when those rights were infringed upon by a judicial decision of a Member State court adjudicating at last instance. ${ }^{27}$ It could have been expected that the decision would cause significant reaction from Member States, which now all of a sudden could have been held liable for decisions of their national courts in violation of EU law. Namely, even while the case was still being discussed, they were extremely concerned that by fully accepting this regime multiple legal principles and concepts, such as judicial independence, ${ }^{28}$ res judicata ${ }^{29}$ or legal certainty ${ }^{30}$ would be violated. However, subsequently both the $\mathrm{CJEU}^{31}$ and legal scholarship ${ }^{32}$ concisely discarded their arguments.

According to the CJEU's viewpoint in Köbler, Member State liability may incur only in exceptional cases when the last instance court has manifestly infringed the applicable law, due to the specific nature of the judicial function and the legitimate requirements of legal certainty. ${ }^{33}$ Whether an infringement is manifest or not

27 Ibid., par. 33. As is the case with Brasserie, the factual background of this case are also well known by now. In summary, Mr Köbler was a German professor who applied for a monetary increment in Austria on the grounds of length of service, available to professors teaching exclusively in Austria for a period of over 15 years. The Austrian court of last instance did not take into account the time Mr Köbler spent as a professor in Germany and rejected his application, which in Mr Köbler's view, infringed his rights stemming from EU law

28 The British goverment in its observation reiterated that the independence of the judiciary within the national constitutional order is a fundamental principle in all Member States. Case C-224/01 - Köbler, par. 26

29 In the observation of the French government, it is pointed out that the principle of res judicata is a fundamental value in legal systems founded on the rule of law, which would be called into question if State liability for infringements of EU law by a judicial body would be recognized. Case C-224/01 Köbler, par. 23

30 The Austrian government observed, among else, that a re-examination of a legal appraisal by a national supreme court would be incompatible with its function of bringing disputes to definitive conclusions. Case C-224/01 - Köbler, par. 21

31 The CJEU already in Köbler ruled with regard to the principle of res judicata that recognition of the principle of State liability for decisions of national courts of last instance does not have the consequence of calling the aforementioned principle into question, since the liability proceedings neither have the same purpose nor the same parties as the proceedings which have acquired res judicata status. The CJEU also pointed out that there is no threat to judicial independence, as the State liability principle concers the liability of the State, and not the personal liability of the judge that rendered the infringing decision. See: Case C-224/01 - Köbler, par. 39 and 42

32 For scholarly arguments that recognized that the principle of State liability does not necessarily go against these principles, see e.g.: Kornezov, A., Res Judicata of National Judgments Incompatible with EU Law: Time for a Major Rethink?, Common Market Law Review, vol. 51, no. 3, 2014, pp. 809-842, p. 841; Scherr, K.M., Comparative Aspects of the Application of the Principle of State Liability for Judicial Breaches, ERA Forum, vol. 12, no. 4, 2012, pp. 565-588, p. 584; Hofstötter, B., Non-compliance of National Courts: Remedies in European Community Law and Beyond, TMC Asser Press, The Hague, 2005, p. $91-107$

33 Case C-224/01 - Köbler, par. 53. Legal scholarship put more emphasis on the legitimate requirements of legal certainty, pointing out that legal certainty based concerns play a bigger role in this regard than 
depends on a number of criteria already established in Brasserie, ${ }^{34}$ but the CJEU here also added a criterion of the national court's compliance with its obligation to make a reference for a preliminary ruling to CJEU. ${ }^{35}$ Nevertheless, one of the main issues with the Köbler decision was that it remained silent in view of the necessary threshold required for a breach to be considered manifest. It did specifically point out that an infringement shall be sufficiently serious if the decision in question manifestly breached previous case-law of the CJEU on the matter, ${ }^{36}$ which was an opinion reiterated in many of its future decisions. ${ }^{37}$ However, even though the Court recognized that individuals must not be deprived of the right to render the State liable for a judicial breach of their rights committed by a court of last instance, ${ }^{38}$ professor Köbler did not obtain reparation because the breach in question was found not to be manifest and therefore not sufficiently serious. ${ }^{39}$ At first glance, one could justifiably assert that by stressing the importance that individuals should always have a remedy at their disposal against the Member State even for judicial breaches, the CJEU strived to introduce a strict liability approach of the Member States. ${ }^{40}$ But at the same time, by not explicitly defining the concept of manifest infringement and therefore not making the prerequisites of that liability clear enough, the remedy system that the CJEU intended to provide a solid footing to was considered in danger of becoming an "empty shell." 41

The CJEU clarified in Traghetti ${ }^{42}$ its standpoint on assessing a manifest infringement to a certain extent, specifically stating that Member State liability in cases of infringements of EU law by national courts of last instance is not unlimited. ${ }^{43}$

the nature of the judicial function as a basis for a strict approach liability of national supreme courts. See: Davies, A., State Liability for Judicial Decisions in European Union and International Law, The International and Comparative Law Quarterly, vol. 61, no. 3, 2012, pp. 585-611, p. 599

34 See supra, note 22, p. 4

35 Case C-224/01 - Köbler, par. 55

36 Ibid., par. 56

37 See e.g.: Case C-620/17 Hochtief Solutions AG Magyarországi Fióktelepe v. Fövárosi Törvényszék [2019] ECLI:EU:C:2019:630 (hereinafter: Case C-620/17 - Hochtief Solutions), par. 43-44. In this decision, the CJEU did not immediately find a manifest infringement even though it already gave a preliminary ruling in the proceedings, which the national courts subsequently apparently went against. It rather determined that the referring national court is to take the manifest disregard of the relevant CJEU decision as one of the factors in establishing whether there was a sufficiently serious breach

38 Case C-224/01 - Köbler, par. 34

39 Ibid., par. 124

40 Rodríguez, op. cit., note 2, p. 612

41 Dam, op. cit., note 20, p. 46

42 Case C-173/03 Traghetti del Mediterraneo SpA v. Italy [2006] ECR I-5177 (hereinafter: Case C-173/03 - Traghetti)

$43 \quad$ Ibid., par. 32 
Furthermore, it provided for the possibility of national law to define more criteria that pertain to the nature or degree of the breach necessary for invoking Member State liability, even though it prohibited such criteria of national law to be stricter than that of a manifest infringement of the applicable law, ${ }^{44}$ which must not be as such to limit the liability exceptionally to cases of intentional fault and serious misconduct on part of the Court. ${ }^{45}$ By holding onto the concept of a manifest infringement, the judgment was welcomed as it would discourage all unsuccessful parties to make a claim for damages whenever a judicial decision is not in their favour. ${ }^{46}$ On the other hand, although Traghetti firmly upheld the Köbler judgment, it would appear that the Member States were subsequently left none the wiser with regard to the determination of when will an infringement be considered manifest. Indeed, it seems that by the decision in question the Court intended to keep only objective factors in play in discerning the liability of Member States, doing away with the previously established factor of fault. ${ }^{47}$ At the same time, CJEU in Traghetti did distinctly refer to, among other Köbler factors, intentional infringement as being an indicator of a manifest infringement. ${ }^{48}$ Legal scholarship interpreted this contradiction as the will of the Court to merely shift the (un)intentionality of an infringement from being a required condition of an infringement to be manifest to the plane of unlawfulness. ${ }^{49}$ The fault criterion therefore retained its subjective nature, although it is determined in accordance with objective standards. ${ }^{50}$

In any event, the fact that the Court did not at all go into further detail with regard to fault and other criteria set out in Köbler, all one could have done to fully comprehend the CJEU's exact stance on the matter was to wait for its subsequent case-law. And although a more specific and comprehensive definition of a manifest infringement is non-existent even today, some of the criteria by which it is established, mainly the non-compliance with the obligation to refer a matter to a preliminary ruling, did receive substantial clarification.

\footnotetext{
$44 \quad$ Ibid., par. 44

45 Ibid., par. 26

46 Anagnostaras, G., Erroneous Judgments and the Prospect of Damages: The Scope of the Principle of Governmental Liability for Judicial Breaches, European Law Review, vol. 31, no. 1, 2006, pp. 735-747, p. 743

47 Beutler, B., State Liability for Breaches of Community Law by National Courts: Is the Requirement of a Manifest Infringement of the Applicable Law an Insurmountable Obstacle?, Common Market Law Review, vol. 46, no. 1, 2009, pp. 773-804, p. 786

48 Case C-173/03 - Traghetti, par. 32

49 Machnikowski, P., The Liability of Public Authorities in The European Union, in: Oliphant, K. (ed.), The Liability of Public Authorities in Comparative Perspective, Intersentia, Cambridge, 2016, p. 583

50 Valutyte, R., Concept of Court's Fault in State Liability Action for Infringement of European Union Law, Jurisprudencija, vol. 18, no. 1, 2011, pp. 33-48, p. 42
} 


\section{MANIFEST INFRINGEMENTS OF EU LAW BY NATIONAL COURTS IN CONTEMPORARY CASE-LAW}

\section{1. - Non-compliance of national courts to make a reference for a preliminary ruling in light of Ferreira da Silva - is the influence of the CJEU over supreme courts of Member States becoming overwhelming?}

One of the factors which may be used to indicate whether an infringement is manifest mentioned in Köbler and Traghetti that mostly gave rise to significant discussion in comparison to others is the non-compliance of the national court to make a reference for a preliminary ruling pursuant to paragraph 3 of Article 267 TFEU. While the function of that rule was at first strictly qualified as securing uniform interpretation and application of EU law and not conferring rights upon individuals, ${ }^{51}$ recent legal developments accepted that the breach of the national courts' duty to refer is complementary with a breach of a substantive individual right. $^{52}$ An example in that regard may be Article 47 of the Charter of Fundamental Rights of the European Union ${ }^{53}$ which guarantees effective judicial protection to every individual. An injured party would not be successful in proving a manifest infringement by merely claiming a breach of Article 267 TFEU; they have to establish that by the national court's failure to refer, their right for effective judicial protection was infringed upon..$^{54}$ The obligation of national courts of last instance to make references for preliminary rulings has always been a rather sensitive issue. Since supreme courts represent the highest judicial authority in a certain Member State, the imposition of obligations on them by the CJEU is never taken quite lightly from a domestic legal perspective, due to the fact that uniformity of EU law may not always be the primary goal of national courts. ${ }^{55}$ It was already considered exaggerated that national courts should refer every single case that within it has an element of EU law, however, a behaviour that would excessively incline in the opposite direction of complete non-referral may potentially have grave negative consequences for national treasuries in cases where the CJEU finds that an infringement did in fact take place. ${ }^{56}$

The question did receive substantive analysis even before Member State liability for judicial breaches was established by Köbler, when the CJEU in the landmark

\footnotetext{
$51 \quad$ Hofstötter, op. cit., note 32, p. 132

52 Ibid., p. 133

53 Charter of Fundamental Rights of the European union, OJ C 326, 26 October 2012

54 Kornezov, A., The New Format of the Acte Clair Doctrine and its Consequences, Common Market Law Review, vol. 53, no. 5, 2016, pp. 1317-1342, p. 1340

55 Hofstötter, op. cit., note 32, p. 108

56 Anagnostaras, op. cit., note 46, p. 745
} 
Cilfit judgment ruled that national courts against the decisions of which there are no judicial remedies available under national law are in fact obliged to bring the matter before the CJEU in cases where EU law is raised before them. ${ }^{57}$ There are three important exceptions to this obligation, which include cases where the national courts have determined that: (i) the question raised is irrelevant, (ii) the CJEU has already interpreted the EU law provision in question (acte éclairé), or (iii) the correct application of EU law is obvious to the degree of leaving no room for any reasonable doubt (acte clair). ${ }^{58}$ The CJEU later confirmed this regime in both Intermodal Transports and X and van Dijk, stressing that deciding whether the aforementioned circumstances are present in a certain case is solely the responsibility of national courts. ${ }^{59}$

A potential issue in that regard appeared in the more recent landmark ruling of Ferreira da Silva ${ }^{60}$ which was the first case in over fifty years where the CJEU found that a national court of last instance breached its obligation to make a reference. ${ }^{61}$ In essence, the Portuguese Supreme Court of Justice dismissed the requests of the applicants to make a reference for a preliminary ruling to CJEU who desired a clarification on whether a decision of their dismissal as a collective redundancy was lawful during an alleged transfer of business between two airline companies. The Supreme Court stated that such an obligation of national courts of last instance "exists only where those courts and tribunals find that recourse to EU law is necessary in order to resolve the dispute before them and, in addition, a question concerning the interpretation of that law has arisen. ${ }^{162}$ Given the previously established position of the CJEU, it did not come as a surprise that it was in disagreement with the Portuguese Supreme Court on the matter; it repeated the Cilfit exceptions of the duty to refer and added that the existence of such exceptions must be assesed in the light of the specific characteristics of EU law, difficulties in its interpretation and the risk of divergences in judicial decisions in the EU. ${ }^{63}$

57 Case C-283/81 CILFIT and others v. Ministry of Health and Lanificio di Gavardo SpA v. Ministry of Health [1982] ECR 3415 (hereinafter: Case C-283/81 - CILFIT). See also: Recommendations to national courts and tribunals in relation to the initiation of preliminary ruling proceedings, OJ C 380, 8 November 2019, para. 6 and 7

58 Case C-283/81 - CILFIT, par. 21

59 Case C-495/03 Intermodal Transports BV v Staatssecretaris van Financiën [2005] ECR I-8151, para. 37; Joined cases C-72/14 and C-197/14 X v. Inspecteur van Rijksbelastingdienst and T.A. van Dijk v. Staatssecretaris van Financiën [2015] EU:C:2015:564, par. 58

60 Case C-160/14 João Filipe Ferreira da Silva e Brito and Others v. Portugal [2015] ECLI:EU:C:2015:565 (hereniafter: Case C-160/14 - Ferreira da Silva)

61 Limante, A., Recent Developments in the Acte Clair Case Law of the EU Court of Justice: Towards a more Flexible Approach, Journal of Common Market Studies, vol. 54, no. 6, 2016, pp. 1384-1397, p. 1391

62 Case C-160/14 - Ferreira da Silva, par. 16

$63 \quad$ Ibid., par. 38-39 
However, the CJEU stated for the first time in Ferreira da Silva that in cases where a legal concept frequently causes difficulties in interpretation in various Member States, a national court against whose decisions there is no judicial remedy must make a reference to the Court "in order to avert the risk of an incorrect interpretation of EU law. " ${ }^{164}$ One may wonder whether by referring to the existence of a risk of an incorrect interpretation of EU law, the scope of the acte clair exception pertaining to the extent of the obligation for making references for preliminary rulings established by Cilfit becomes even more obfuscated when viewed from the perspective of Köbler as a factor in determining whether a breach was manifest. It is true that if the CJEU had already interpreted a provision of EU law and confirmed its interpretation multiple times in subsequent case-law, the situation should be clear enough for the national courts of last instance to prevent the need from referring the question for a preliminary ruling. Advocate General Bot adequately stressed the extreme importance of the matter of referrals, by stating that non-compliance to refer a question for a preliminary ruling consequently deprives the CJEU of its fundamental task to ensure that the law is observed in the interpretation and application of the Treaties. ${ }^{65}$ The judgment in Ferreira da Silva may therefore be regarded by some academics as the CJEU's attempt to cease the abusive use of the acte clair doctrine which had been happening within many national courts. ${ }^{66}$ Other parts of scholarship that commented it in a positive manner saw it as a method of dialogue enhancement between the CJEU and national supreme courts, by providing the latter with more trust and responsibility as 'European courts' and in that way decentralizing various areas of EU law. ${ }^{67}$

While the CJEU did rule in Ferreira da Silva that the concept of a transfer of a business has given rise to a great deal of uncertainty on the part of a larger number of national courts and tribunals $s^{68}$ and provided sufficient explanation for that

64 Ibid., par. 44; The judgment is also noteworthy due to the fact that it removes another barrier of obtaining compensation by determining that EU law precludes a provision of national law which requires, as a precondition, the setting aside of the decision of the court of last instance which caused the damage, when such setting aside is practically impossible. See: Case C-160/14 - Ferreira da Silva, par. 60; This will affect not only the Portuguese legal system, but also the domestic legal systems of Belgium, the Czech Republic, Cyprus, Finland, Slovakia and Sweden, where such national law provisions exist. See to that extent: Varga, Z., Why is the Köbler Principle not applied in Practice, Maastricht Journal of European and Comparative Law, vol. 23, no. 6, 2016, pp. 984-1008, p. 990

65 Case C-160/14 João Filipe Ferreira da Silva e Brito and Others v. Portugal [2015] ECLI:EU:C:2015:390, Opinion of AG Bot, par. 102

66 Cairó Ruiz, E., Joined cases C-72/14 and C-197/14 X and case C-160/14 Ferreira da Silva: is the ECJ reversing its position on the acte clair doctrine?, 23 September 2015, European Law Blog, [https:// europeanlawblog.eu/2015/09/23/] , accessed 18. March 2020

67 Kornezov, op. cit., note 54, p. 1328

68 Case C-160/14 - Ferreira da Silva, par. 43 
specific concept ${ }^{69}$ further general factors for determining when and if a particular legal concept gives rise to difficulties in interpretation were not stated. This omission could prove to be an issue in the future; since both EU law and national legal systems of the Member States are a constantly developing and changing legal areas, the subject of the overwhelming majority of cases before national courts of last instance in which EU law is in some way referred to, may very easily be a legal concept whose correct interpretation from the viewpoint of the CJEU could potentially leave room for reasonable doubt, as was in fact the case in Ferreira da Silva. As a consequence, the majority of such cases may carry a certain degree of risk of incorrect interpretation of that concept from an EU law standpoint. Taking into account that it was previously ascertained by the CJEU that national courts may completely freely refer questions which are already considered to be well-established in EU and national case-law, ${ }^{70}$ it remains dubious, if Ferreira da Silva is to be applied consistently, why national courts of last instance against whose judgment there is no remedy should not simply, in order to fully avert the risk of misinterpreting EU law or the level of establishment of its case-law, refer every question in relation to the interpretation of EU law for a preliminary ruling. One could therefore argue that Ferreira da Silva reinstates on the part of national courts of last instance a deterrent effect with regard to non-compliance with the obligation to refer. ${ }^{71}$ It presents to national courts an uncomfortable contemporary reminder that it is in fact fully possible that failure to do so will potentially open their Member State to liability in damages for committing a manifest infringement of applicable law and consequently have negative effects on the public perception of the quality of their national judicial system, as well as undesirable economic strains on the national budget.

A resolute solution to this discussion does not seem to be quite clear in legal scholarship and attracts many opposed opinions. A part of legal doctrine already noticed that mere references to the Cilfit criteria do not represent sufficient guidance to national courts with regard to their discretional limits in the interpretation of EU law and that the literal application of those criteria may lead to the conclu-

69 Ibid., par. 24-27

70 Case C-260/07 Pedro IV Servicios SL v. Total España SA [2009] ECR I-2437, par. 31. In this case, the CJEU explicitly acknowledged that a reference for a preliminary ruling cannot be determined inadmissible simply because the questions referred are already settled in well-established EU and national case-law, or even if a referred question is materially identical to previously referred questions. In other words, there are no negative consequences or sanctions for making a reference for a preliminary ruling

71 The subject judgment also puts into question previous opinions of legal doctrine which held that instituting proceedings for a breach of EU law due to non-compliance of national courts of last instance to their duty to refer is not an efficient way of enforcing that obligation. See: Lenaerts, K.; Maselis, I.; Gutman, K., EU Procedural Law, Oxford University Press, 2014, p. 102 
sion that the CJEU indeed intended to discourage national courts from acte clair considerations in the first place. ${ }^{72}$ One did not even have to wait until Ferreira da Silva; not long after Köbler certain scholars distinctly pointed out the growing concern that a highest national court that does not want to make its Member State liable should ask for a preliminary ruling in every case involving a question of a EU law provision that confers rights on individuals which was not yet answered by the CJEU. ${ }^{73}$ This issue was also raised by the British governement in Köbler itself, which argued that the acceptance that national courts may make errors in EU law interpretation is inherent in their freedom to decide matters of EU law and that making them liable for its misinterpretation will not be beneficial for the relationship between national courts and the CJEU. ${ }^{74}$ On the other hand, differing opinions of the immediate post-Köbler period claimed that courts that act bona fide in the application of EU law will not render the Member State liable, ${ }^{75}$ as was determined in British Telecommunications. ${ }^{76}$ The remedy of Member State liability for judicial acts is considered so exceptional that it will not result in a disbalance of power between national courts and the CJEU. ${ }^{77}$ Advocate General Léger in Köbler also reiterated that in order to assess whether a national supreme court has committed an infringement, the decisive factor is not the failure to refer, but whether its error of law was excusable or inexcusable. ${ }^{78}$

Nevertheless, the fact remains that in Ferreira da Silva the CJEU held that the Portuguese Supreme Court indeed should have made a reference, without discussing whether it acted bona fide or whether such an error was excusable or not. It remains to be seen if the subject omission of the Portuguese Supreme Court will be considered grave enough to be considered manifest and justify an award in damages. But in any event, by referring to the notion of the aversion of risk of incorrect interpretation of EU law as an argument in favour of making references for preliminary rulings and by determining that a national court of last instance did not comply with that obligation, while concurrently establishing that non-compliance to refer is a criterion for determining if a judicial infringement was manifest, the incentive of national supreme courts to interpret on their own

\footnotetext{
72 Limante, op. cit., note 61, p. 1394 and 1386

73 Wattel, P.J., Köbler, Cilfit and Welthgrove: We can't go on meeting like this, Common Market Law Review, vol. 41, no. 1, 2004, pp. 177-190, p. 178

74 Case C-224/01 - Köbler, par. 27

75 Hofstötter, op. cit., note 32, p. 119-120

76 Case C-392/93 The Queen and H.M. Treasury, exparte: British Telecommunications [1996] ECR I-1631, par. 43

77 Hofstötter, op. cit., note 32, p. 119

78 Case C-224/01 Gerhard Köbler v Republik Österreich [2003] ECR-I-10239, Opinion of AG Léger, par. 139 and 153
} 
whether a particular legal concept is already clearly defined and well-established in EU case-law becomes considerably blurred. Therefore, at this time one may only claim that the way in which both the CJEU and the national courts of last instance will further handle this issue and additionally interpret the acte clair doctrine in view of Ferreira da Silva for the time being remains strongly anticipated.

\section{2. - The issues of lower national courts as potential tortfeasors and national procedural autonomy}

The judgment in Köbler had two further notable obscurities that subsequent caselaw had to address. Firstly, despite the fact that the case concerned infringements of EU law allegedly committed by the Austrian Supreme Administrative Court, it did not explicitly state whether the liability framework for manifest infringements done by the judiciary also includes lower national courts. The second problem pertained to the question of whether the Member State may be held liable in accordance with Köbler regardless of the fact that other usual legal remedies have not been utilized by the injured person, as well as the fact that applicable national law concurrently provides for different types of remedies, for example, an action for unjust enrichment against the tortfeasor. These questions are suitable to be analyzed simultaneously due to their complementarity.

First of all, it was believed that the intention of the CJEU was to actually recognize liability only in cases of breaches committed by courts of last instance. This could be concluded by referring to the CJEU's viewpoint on national procedural autonomy, which approves the principle of primacy of appellate review. ${ }^{79}$ While the CJEU in Francovich did state that every Member State may designate the competent courts and establish procedural rules for safeguarding individuals' rights that stem from EU law, ${ }^{80}$ it already in Brasserie manifested a more restrained approach, referring to the principle of equivalence and effectiveness as justifications for the limitations of procedural autonomy of Member States. ${ }^{81}$ Namely, the principle of equivalence assumes that procedural conditions of national law governing actions for damages due to infringements of EU law must not be less favourable to the plaintiff than those relating to similar actions of domestic nature, while the principle of effectiveness implies that it must not be practically impossible for the plaintiff to exercise rights

\footnotetext{
79 Scherr, K.M., The Principle of State Liability for Judicial Breaches: The case Gerhard Köbler v. Austria under European Community Law and from a Comparative National Law Perspective, Doctoral Dissertation, European University Institute, 2008, [https://cadmus.eui.eu/handle/1814/13165], accessed 19. March 2020, p. 38-39

80 Joined cases C-6/90 and C-9/90 Francovich and Bonifaci et al. v Italy [1991] ECR I-5357, par. 42

81 Joined cases C-46/93 and C-48/93 - Brasserie, par. 67
} 
which the national courts must protect. ${ }^{82}$ These two principles were reaffirmed and referred to by the CJEU on many instances in its case-law since they were first mentioned. ${ }^{83}$ On the other hand, the CJEU previously also established that not only do the national courts have to take care of the consistent application of these principles, but injured parties also have the obligation to show reasonable dilligence in limiting the extent of the damage which they suffered, or risk having to bear it themselves. ${ }^{84}$ When proceedings are at the point when they take place before lower national courts, appellate review for alleged judicial wrongs is at the disposal of the injured party in virtually every Member State, ${ }^{85}$ which is why such an option was considered to preclude Member State liability for manifest judicial infringements of EU law committed by lower national courts. ${ }^{86}$

Taking the above into account, the recent judgment of the CJEU in the Tomásová case $^{87}$ provided notable clarification on both fronts. The case, in essence, regarded the applicant's claim in damages against Slovakia for the breach of a District court, which upheld the judgment of an arbitral tribunal that ordered payment against the applicant, whose competence was established on the basis of an allegedly unfair contractual term. ${ }^{88}$ The District Court referred the matter for a preliminary ruling, asking in essence may liability of a Member State arise before exhausting all available legal remedies, as well as exhausting the possibility of a claim for unjust enrichment, and if so, whether such conduct of the authority in the main proceedings represents a sufficiently serious breach of EU law. The matter of methods in

82 Brüggemeier, op. cit., note 18, p. 83-84. See also: Case C-69/14 Dragoș Constantin Târşia v. Statul român and Serviciul Public Comunitar Regim Permise de Conducere si Inmatriculare a Autovehiculelor [2015] ECLI:EU:C:2015:662, where these principles were specifically analyzed in more detail by the CJEU. For an in-depth doctrinal analysis of the prinicple of effectiveness, see: Reich, N., The Principle of Effectiveness and EU Private Law, in: Bernitz, U.; Groussot, X.; Schulyok, F (eds.), General Principles of EU Law and European Private Law, Wolters Kluwer, 2013, pp. 301-325

83 They were first referred to by the CJEU in Case C-33/76 Rewe-Zentralfinanz e $G$ and Rewe-Zentral AG v. Landwirtschaftskammer für das Saarland [1976] ECR I-1989 and Case C-45/76 Comet BV v. Produktschap voor Siergewassen [1976] ECR I-2043. See also e.g.: Case C-160/14 - Ferreira da Silva, par. 43; Case C-429/09 Günter Fuß v. Stadt Halle [2010] ECR I-12167, par. 62; Case C-118/08 Transportes Urbanos y Servicios Generales SAL v. Administración del Estado [2010] ECR I-635, par. 31

84 See e.g. Joined cases C-46/93 and C-48/93 - Brasserie, par. 85

85 Moreover, some Member States provide for explicit rules in their Civil code stating that State liability may not be invoked before the injured party has exhausted all legal remedies. See e.g. $\$ 839$ (3) of the German Bürgerliches Gesetzbuch (BGBl. I S. 42, 2909; 2003 I S. 738) which provides that liability for damage will not arise if the injured person has intentionally or negligently failed to avert the damage by having recourse to appeal

86 Scherr, op. cit., note 79, p. 39

87 Case C-168/15 Milena Tomášová v. Slovakia - Ministerstvo spravodlivosti SR and Pohotovost's.r.o. [2016] ECLI:EU:C:2016:602 (hereinafter: Case C-168/15 - Tomášová)

88 Ibid., par. 5-14 
which the damage is to be assessed were also referred to the CJEU; the referring court wanted to determine whether the damage amounts to the sum claimed by the applicant, or the sum that would constitute unjust enrichment. ${ }^{89}$

On the subject of national procedural autonomy related to remedies, the CJEU reiterated that the relationship between the ordinary legal remedies and the claim for damages due to an infringement of EU law relies should be established according to the provision of national law of Member States with respect to the principles of equivalence and effectiveness. ${ }^{90}$ That perspective also applies to the relationship between an action for damages caused by a breach of EU law and other legal actions available in the legal system of a particular Member State, such as the action for unjust enrichment. ${ }^{9192}$

With regard to the question of Member State liability only for infringements committed by national courts of last instance, Advocate General Wahl stated in his opinion that such a conclusion seems to now be settled in CJEU's case-law, ensuring a fair balance between the necessity of effective guarantee of individuals' rights stemming from EU law and the specific features of the intervention of judicial bodies in Member States, as well as the difficulties that national courts face in the exercise of the judicial function..$^{93}$ The CJEU, although not explicitly citing the Advocate General's reasoning, did in fact agree with his perspective. It unambiguously pointed out for the first time that Member State liability for damage caused to individuals due to an infringement of EU law by a national court's decision, may be incurred only where it is made by a Member State court of last instance. ${ }^{94}$ However, no further explanation was given at the time, possibly because such an opinion is fully in line with the Court's previous determinations in Köbler and Traghetti.

In subsequent decisions, the CJEU confirmed this approach, explicitly referring to recourse to a judicial remedy as the appropriate means of redressing breaches of EU law from lower national courts. ${ }^{95}$ Although the non-contractual liability of

\footnotetext{
89 Ibid., par. 15

$90 \quad$ Ibid., par. 39

91 Ibid., par. 40

92 Examples of other alternative remedies may include a retrial (in Denmark, Finland, Lithuania, Malta, Sweden and the United Kingdom) and a constitutional complaint (in Austria, Belgium, Croatia, Cyprus, the Czech Republic, Germany, Hungary, Latvia, Slovakia, Slovenia and Spain). See: Varga, op. cit., note 64, p. 994 and 997

93 Case C-168/15 Milena Tomášová v. Slovakia - Ministerstvo spravodlivosti SR and Pohotovost's.r.o. [2016] ECLI:EU:C:2016:260, Opinion of AG Wahl, par. 40

94 Case C-168/15 - Tomášová, par. 36

95 Joined cases C-447/17 P and C-479/17 P European Union and Guardian Europe Sàrl [2019] ECLI:EU:C:2019:672, par. 78
} 
the European union is a matter that exceeds the scope of this paper, it is useful to mention that this perspective was also applied by the CJEU on the level of the EU in this ruling. Namely, the CJEU stated in Guardian Europe Sàrl that the characteristics of the EU's judicial system enable the General Court to be equated to a Member State court not adjudicating at last instance, as a result of which infringements of EU law arising from a decision of the General Court cannot invoke the liability of the EU. ${ }^{96}$ Should then the CJEU be equated with a national court of last instance and therefore be potentially held liable for a manifest infringement of EU law? Wattel seems to think so and refers to this equation as a "requirement of justice", pointing out numerous times in which it could have been considered that the CJEU also erred in interpretation of EU law. ${ }^{97}$ But since the CJEU remains the highest authority on the interpretation of EU law, it is unlikely that it would, at least in the near future, agree to such an arrangement and hold itself liable for infringements of EU law or develop a new liability system in which its decisions could come under judicial review by another court. ${ }^{98}$

Looking back at the principle of primacy of appellate review present across the domestic legal systems of the Member States, it appears that it has nowadays attained official uphodling by the ruling in Tomásová. Therefore, an action for damages suffered by an infringement of EU law committed in a decision of a national court of last instance is confirmed to be a remedy of the very last resort, as long as a national legal provision does not explicitly state otherwise. Varga reaches the same conclusion, claiming that this even seems to be the general idea inspiring the EU liability case-law. ${ }^{99}$ Considering the above, one could, by analyzing Tomášová and the previous case-law on the subject, attain an impression that the procedural institute of a claim for damages sustained by a manifest infringement of EU law by the judiciary is quite efficient and well-established, as long as it is accepted to be the ultimate legal remedy for such a breach. While that impression is indeed correct from a purely theoretical point of view, such actions will unavoidably run into some practical problems which shall be discussed in the following sub-chapters.

96 Joined cases C-447/17 P and C-479/17 P European Union and Guardian Europe Sàrl [2019] ECLI:EU:C:2019:672, par. 82 and 84

${ }_{97}$ Wattel, op. cit., note 73, p. 184

98 AG Léger in his Opinion on Köbler stated that it cannot be inferred that the rules governing Member State liability and the rules governing EU liability should develop in strict parallel. He additionally points out that the EU may not be held liable for a decision of the CJEU, due to the fact that it is the supreme court in the EU legal order. See: Case C-224/01 Gerhard Köbler v Republik Österreich [2003] ECR-I-10239, Opinion of AG Léger, par. 94

99 Varga, Z., National Remedies in the Case of Violation of EU Law by Member State Courts, Common Market Law Review, vol. 54, no. 1, 2017, pp. 51-80, note 99 on p. 69 


\section{3. - Difficulty of establishing a direct causal link}

The concept of Member State liability for EU law infringements committed by national courts has a strong theoretical foundation and elaboration. However, it may not always function with such a degree of quality in practice. As hinted in the title of this sub-chapter, one of the key issues that injured parties will face in their claims for damage compensation is to satisfy the liability condition of the direct causal link between the breach and the damage suffered. Although a deeper analysis of the theoretical background of this legal condition exceeds the scope of this paper, mainly due to the fact that many different Member States have different legal regulations of causation, ${ }^{100}$ it will be briefly reflected upon here, as it may present one of the main obstacles in acheiving damage reparation for infringements of EU law committed by national courts of last instance.

Since causation most often represents a quaestio facti, the CJEU is not very keen on providing detailed explanation of a direct causal link and early on tended to leave that question to the national courts to be determined in accordance with provisions of national law. Legal doctrine noticed a short while after Francovich and Brasserie that the State may be viewed as too remote from the actual damage to be responsible for its causation, stressing that leaving such questions to national law could potentially fail to acheive a desired result. ${ }^{101}$ It is possibly for this reason that the CJEU did show in the cases of Brinkmann ${ }^{102}$ and Rechberger ${ }^{103}$ an inclination towards a perspective that the matter of the existence of a direct causal link should stay with the national legal systems, but that it must be analyzed according to EU law principles, ${ }^{104}$ namely, the principles of equivalence and effectiveness. ${ }^{105}$ However, even though the CJEU did decide that there was a direct causal link

100 This also leads to a different percentage of number of failed claims as a result of a failure to establish the existence of a causal link, especially when Angloamerican and Continental European legal systems are compared. See: Lock, T., Is Private Enforcement of EU Law Through State Liability a Myth? An Assessment 20 years after Francovich, Common Market Law Review, vol. 49, No. 5, 2012, pp. 1675-1702, p. 1689

101 Smith, F.; Woods, L.; Causation in Francovich: The Neglected Problem, The International and Comparative Law Quarterly, vol. 46, no. 4, 1997, pp. 925-941, p. 935-936

102 Case C-319/96 Brinkmann Tabakfabriken GmbH v. Skatteministeriet [1998] ECR I-5255

103 Case C-140/97 Walter Rechberger, Renate Greindl, Hermann Hofmeister and Others v. Republik Österreich [1999] ECR I-3499

104 Biondi; Farley, op. cit., note 2, p. 59. See also: Vaitkevičiūtè, A., Member States Liability in Damages for the Breach of European Union Law - Legal Basis and Conditions for Liability, Jurisprudence, vol. 18, no. 1, 2011, pp. 49-68, p. 61

105 Tomulić Vehovec, M., The Cause of Member State Liability, European Review of Private Law, vol. 20, no. 3, 2012, pp. 851-880, p. 855 
between the breach of the State and the damage suffered in Rechberger, ${ }^{106}$ this will not be a simple task when it comes to infringements commited by national supreme courts.

If one observes, as an example, the notion of manifest infringement of EU law by a decision of a national court of last instance for non-compliance to the obligation to refer a matter for a preliminary ruling, causation will almost certainly impede the attempt to obtain reparation. By failure to refer a matter which may be considered dubious, the national supreme court is in breach of the third paragraph of Article 267 TFEU. On the other hand, the injured party suffers damage as a result of a breach of a substantive rule which confers rights on individuals, and not as a result of the infringement of Article 267 TFEU itself. ${ }^{107}$ Kornezov demonstrates the core of this issue by providing a reverse hypothesis, stating that if a judgment of a national court is actually determined to be compatible with EU law, the substantive right remains unaffected by the failure to make a reference. ${ }^{108}$ It could be concluded that even if non-compliance with the duty to refer may go towards establishing that an injured party indeed suffered a manifest and a sufficiently serious breach, the Member State will manage to avoid liability on the grounds of non-existence of a direct causal link between the breach and the damage. ${ }^{109}$ Does this indicate that a Member State may be held liable for judicial breaches only when the injured party relies exclusively on other criteria of determining a manifest infringement, such as the excusability of the error of law or the degree of clarity and precision of the infringed rule? That could possibly be so, but it would be better to be cautious and wait for the CJEU's more detailed guidance on the relationship between the concept of a manifest infringement of EU law by national courts of last instance and the notion of a direct causal link in such cases, before attempting to provide a more definite answer.

A step forward has recently been taken in that regard by the European Court of Human Rights, which demonstrated that injured persons are not completely devoid of the possibility of acheiving redress, even when faced with the problem of establishing a direct causal link. In Schipani and others v. Italy, the ECtHR found that the Italian Court of Cassation breached its obligation to refer a matter for a preliminary ruling, which was sufficient to establish an infringement of Article 6 paragraph 1 of the European Convention on Human Rights and Fundamental

\footnotetext{
106 Case C-140/97 Walter Rechberger, Renate Greindl, Hermann Hofmeister and Others v. Republik Österreich [1999] ECR I-3499, par. 75

107 See supra, notes 51 and 52, p. 7-8

108 Kornezov, op. cit., note 32, p. 1332

109 See also Rodriguez, op. cit., note 2, p. 618, where a similar conclusion was reached
} 
Freedoms. ${ }^{110111}$ Irrespective of the infringement itself, the ECtHR pointed out that there is no causal link between this violation and the material damage that the applicants suffered, but it still recognized that the applicants sustained nonmaterial damage as a result of the infringement, for which they were in fact compensated. ${ }^{112}$ Therefore, until a better reconciliation of the concepts of a manifest infringement and a direct causal link is attained, plaintiffs in actions against Member States for failure of their national courts of last instance to refer a matter for a preliminary ruling will be unsuccessful to obtain reparation of material damage, ${ }^{113}$ and should instead place the focus on their claim in non-material damages if they want to be compensated at least to a certain degree.

\section{4. - Damage assessment and the problem of the infringement-committing court deciding about the damages for that infringement}

Another issue that arises in relation to judicial infringements of EU law and that is tightly connected with the relationship between EU and national rules is the extent of compensation that the injured party should receive. According to the viewpoint of the CJEU, the criteria for determining that extent should be provided within national law of Member States, with the observance of not only the principles of equivalence and effectiveness, ${ }^{114}$ but also that reparation is commensurate with the loss or damage sustained in order to achieve effective protection of individuals' rights. ${ }^{115}$ In other words, when it comes to material damage, both actual loss and loss of profits fall within the scope of compensation which the injured party may receive. ${ }^{116}$ The CJEU specifically stated in Brasserie that exclusion of loss of profits as a head of compensable damage would be contrary to the principle of effectiveness. ${ }^{117}$

Furthermore, even though actual loss is usually the easiest head of damage to prove, it could be possible that certain provisions of national laws preclude the

110 European Convention for the Protection of Human Rights and Fundamental Freedoms, as amended by Protocols Nos. 11 and 14, 4 November 1950, ETS 5

111 For a more detailed analysis of the perspective of the ECtHR on preliminary references to the CJEU, see: Lacchi, C., Multilevel Judicial Protection in the EU and Preliminary References, Common Market Law Review, vol. 53, no. 3, 2016, pp. 679-707, p. 698

112 Judgment Schipani and Others $v$ Italy, Application No. 38369/09, par. 87

113 There may be an exception to this, as recently demonstrated in Hochtief Solutions where it was ascertained that costs of proceedings constitute material damage which may be recovered. See: infra, note 119 , p. 17

114 Case C-168/15 - Tomášová, par. 39

115 Joined cases C-46/93 and C-48/93 - Brasserie, par. 83

116 Biondi; Farley, op. cit., note 2, p. 77

117 Joined cases C-46/93 and C-48/93 - Brasserie, par. 91 
injured party to obtain compensation for a particular form of actual loss. In that regard, the CJEU has never refrained from striking down such provisions. ${ }^{118} \mathrm{~A}$ most recent example may be the ruling in Hochtief Solutions where the CJEU held that the costs of proceedings that a party incurred as a result of an infringement of a rule of EU law by a decision of national court of last instance are also included in damage that may be restituted, as an opposite provision of Hungarian law rendered it virtually impossible to obtain adequate compensation. ${ }^{119}$

Finally, some scholars also warned about the practical problem of the national court of last instance which will potentially have to decide about reparation of damages caused by a manifest infringement of EU law within a decision of that same court. Indeed, if a court of last instance allegedly committed a breach of EU law within its judicial decision, the injured party would in most Member States initiate restitution proceedings before a local court, after which the case may, on appeal, again arrive before the court of last instance. Van Dam indicates that this could further reduce the injured party's chances to have access to an effective remedy. ${ }^{120}$ Wattel goes even further and unambiguously states that legal protection of individuals is ineffective if the same highest national court which committed a manifest infringement is competent to review that decision. ${ }^{121122}$ He continues by stating that the Member States will all have to create special procedures in order to tackle this issue, which will consequently result in more preliminary referrals, more procedure in general and more congestion of the CJEU. ${ }^{123}$

\footnotetext{
118 Biondi; Farley, op. cit., note 2, p. 79

119 Case C-620/17 - Hochtief Solutions, par. 47

120 Dam, op. cit., note 20, p. 47

121 Wattel, op. cit., note 73, p. 180

122 If the matter in question does not receive adequate attention and resolution, it may potentially lead to continuous ineffectiveness of legal protection of individuals' rights, i.e. to systemic violations of the principle of effectiveness, which could then create a further problem for Member States - the initiation of the "infringement procedure" against them pursuant to Articles 258, 259 and 260 TFEU (Lisbon). Failure by a Member State to act in accordance with the CJEU's judgment and remedy the subject infringement may even result in the imposition of financial sanctions against that Member State by the CJEU, either as a lump sum or a penalty payment. For a more detailed discussion about the infringement procedure, see: Ćapeta, T., Sudski sustav Europske unije i njegov utjecaj na procesna prava država članica, in: Garašić, J. (ed.), Europsko građansko procesno pravo - izabrane teme, Narodne novine, Zagreb, 2013, pp. 33-55; Petrašević, T.; Dadić, M., Infringement procedures before the Court of justice of the EU, Pravni vjesnik, vol. 29, no. 1, 2013, pp. 77-98.; Radivojević, Z.; Raičević, N., Financial sanctions against Member States for infringement of EU law, in: Duić, D.; Petrašević, T. (eds.), Procedural aspects of EU law - EU and comparative law issues and challenges series, Faculty of Law Osijek, 2017, pp. 171-191; Duić, D.; Petrašević, T., Pet godina primjene prava Europske unije - Analiza postupaka zbog povrede prava Europske unije pokrenutih protiv Republike Hrvatske i prethodnih pitanja hrvatskih sudova, Godišnjak Akademije pravnih znanosti Hrvatske, vol. 10, no. 1, 2019, pp. 65-95 Ibid., p. 181
} 
One may look towards the legislative branch for solutions to the subject procedural hurdle. Italy is a rare example of an EU Member State in which legislative recognition of the concept of a manifest infringement has already happened. ${ }^{124}$ Other Member States, however, do not show a tendency to make any legislative changes in order to widen the liability of their judiciary. Although in some Member States there actually is a certain amount of willingness to apply the notion of manifest infringement in their decisions, it is demonstrated through judicial decisions, rather than legislative action. ${ }^{125}$ However, this does not represent a sturdy solution to the subject problem, since occurrences of the same supreme court that decides a claim of damage restitution for a manifest infringement which that court committed may still easily happen. Either all Member States should therefore make special procedural changes which would prevent such a situation from occurring, or the CJEU should attempt to carefully reconcile this issue with the principle of effectiveness.

\section{CONCLUSION}

When we turn around and look back at the previous twenty years of the development of the framework of liability of Member States for infringements of EU law caused by the decisions of national courts of last instance, nobody could deny that there have been significant improvements to its theoretical and practical foundations. With the CJEU at the commands, the concept of this liability has been continuously shaped throughout the years, not only in order to strenghten the cooperation between the CJEU and the national supreme courts, but also more importantly, to achieve a satisfactory degree of effectiveness of EU law from the viewpoint of its citizens. While in the past it was merely hinted upon that damages may be awarded to individuals as a result of a breach of EU law by a national judicial organ, nowadays such a remedy is well-established within Europe and at the disposal of every individual who has suffered such a breach.

However, although the existence of an action against a Member State for judicial infringements is quite accepted, the research has demonstrated that individuals who desire to pursue such an action will meet several practical impediments which

124 Legge 13 aprile 1988, n. 117., GU 15 aprile 1988, n. 8, as amended by Legge 27 febbraio 2015, n. 18, GU 4 marzo 2015, n. 52. The Act is colloquially known as the Vassalli Act on Civil Liability of Judges. Article 2 par. 3. explicitly states that a manifest infringement of EU law constitutes fault, while Article 4 provides for the competence of courts of appeal to hear such cases. It is interesting to mention that in cases where the judge who has committed a manifest infringement of EU law with fault or gross negligence, the State is obliged to bring an action against the judge for reimbursement of compensated damage (Article 7. par. 1.)

125 Varga, op. cit., note 64, p. 992 
seriously place its efficiency into question. Firstly, they will have to be certain that they have used all ordinary legal remedies at their disposal, as well as that other similar actions, such as a claim for unjust enrichment, a retrial or a constitutional complaint, cannot be or have also already been used in their case. Secondly, if there are no other remedies available, or they have all already been utilized, an individual may then commence an action against the Member State, but a manifest infringement of the national court of last instance is going to have to be proven by the individual. This presupposes that the individual will be able to establish that a national supreme court incorrectly interpreted a substantive EU legal norm or went against well-established case-law of the CJEU and at the same failed to provide sufficient reasons as to why did it not refer the matter for a preliminary ruling. The bar has indeed in this regard been set very high, and the case-law of the CJEU confirms such a perspective; the number of successful Member State liability cases based on conditions set by Köbler have indeed been extremely low, as breaches of obligations of national courts were very rarely ascertained. Thirdly, the most persistent individuals who have managed to tackle the first two obstacles will then also have to prove the existence of a direct causal link between the manifest infringement and the damage suffered. In present case-law, cases of manifest infringements by national courts of last instance have almost exclusively had to do with the criterion of non-compliance with their obligation to refer. In these cases, a direct causal link between the breach and the suffered material damage has been virtually impossible to establish, while on the other hand, some positive steps have been taken by the ECtHR to ensure the prospect of non-material redress for the injured parties. Lastly, in most Member States, even if individuals are successful in all of the above, they will still potentially have to face the daunting notion that their damage compensation case may then arrive before the same court that committed the manifest infringement and from that point on, merely hope that they will obtain redress.

It is doubtful to what extent may the principles of eqiuvalence and effectiveness be satisfied by imposing such strict practical barriers for obtaining reparation. The liability framework is undoubtedly a huge step forward for proper protection of individuals' rights conferred by EU rules, but the existing number of conditions and the overall standard of this liability remains too high for it to be called theoretically and practically effective. The CJEU should face this issue in its future case-law and "loosen the grip" on the strict interpretation of the necessary criteria for establishing Member State liability. Otherwise, if the number of cases where individuals actually managed to receive compensation of their damage remains insignificantly low when compared to cases in which their actions failed, the entire liability framework does indeed face the dangerous prospect of becoming "an empty shell." 


\section{REFERENCES}

\section{BOOKS AND ARTICLES}

1. Alto, P., Twelve Years of Francovich in the European Court of Justice: A Survey of the Case-law on the Interpretation of the Three Conditions of Liability, in: Moreira de Sousa, S., Heusel, W. (eds.), Enforcing Community Law from Francovich to Köbler: Twelve Years of the State Liability Principle, Academy of European Law, vol. 37, 2004, pp. 59-77

2. Anagnostaras, G., Erroneous Judgments and the Prospect of Damages: The Scope of the Principle of Governmental Liability for Judicial Breaches, European Law Review, vol. 31, no. 1, 2006, pp. 735-747

3. Beutler, B., State Liability for Breaches of Community Law by National Courts: Is the Requirement of a Manifest Infringement of the Applicable Law an Insurmountable Obstacle?, Common Market Law Review, vol. 46, no. 1, 2009, pp. 773-804

4. Biondi, A.; Farley, M., The Right to Damages in European Law, Wolters Kluwer, 2009

5. Brüggemeier, G., Tort Law in the European Union, Wolters Kluwer, 2015

6. Ćapeta, T., Sudski sustav Europske unije i njegov utjecaj na procesna prava država članica, in: Garašić, J. (ed.), Europsko građansko procesno pravo - izabrane teme, Narodne novine, Zagreb, 2013, pp. 33-55

7. Dam, C. van, European Tort Law, Second Edition, Oxford University Press, 2013

8. Davies, A., State Liability for Judicial Decisions in European Union and International Law, The International and Comparative Law Quarterly, vol. 61, no. 3, 2012, pp. 585-611

9. Duić, D.; Petrašević, T., Pet godina primjene prava Europske unije - Analiza postupaka zbog povrede prava Europske unije pokrenutih protiv Republike Hrvatske i prethodnih pitanja hrvatskih sudova, Godišnjak Akademije pravnih znanosti Hrvatske, vol. 10, no. 1, 2019, pp. 65-95

10. Hofstötter, B., Non-compliance of National Courts: Remedies in European Community Law and Beyond, TMC Asser Press, The Hague, 2005

11. Kornezov, A., Res Judicata of National Judgments Incompatible with EU Law: Time for a Major Rethink?, Common Market Law Review, vol. 51, no. 3, 2014, pp. 809-842

12. Kornezov, A., The New Format of the Acte Clair Doctrine and its Consequences, Common Market Law Review, vol. 53, no. 5, 2016, pp. 1317-1342

13. Lacchi, C., Multilevel Judicial Protection in the EU and Preliminary References, Common Market Law Review, vol. 53, no. 3, 2016, pp. 679-707

14. Lenaerts, K.; Maselis, I.; Gutman, K., EU Procedural Law, Oxford University Press, 2014

15. Limante, A., Recent Developments in the Acte Clair Case Law of the EU Court of Justice: Towards a more Flexible Approach, Journal of Common Market Studies, vol. 54, no. 6, 2016, pp. 1384-1397

16. Lock, T., Is Private Enforcement of EU Law Through State Liability a Myth? An Assessment 20 years after Francovich, Common Market Law Review, vol. 49, no. 5, 2012, pp. 1675-1702

17. Machnikowski, P., The Liability of Public Authorities in The European Union, in: Oliphant, K. (ed.), The Liability of Public Authorities in Comparative Perspective, Intersentia, Cambridge, 2016 
18. Petrašević, T.; Dadić, M., Infringement procedures before the Court of justice of the EU, Pravni vjesnik, vol. 29, no. 1, 2013, pp. 77-98

19. Radivojević, Z.; Raičević, N., Financial sanctions against Member States for infringement of EU law, in: Duić, D.; Petrašević, T. (eds.), Procedural aspects of EU law - EU and comparative law issues and challenges series, Faculty of Law Osijek, 2017, pp. 171-191

20. Rebhahn, R., Non-Contractual Liability in Damages of Member States for Breach of Community Law, in: Koziol, H.; Schulze, R. (eds.), Tort Law of the European Community, SpringerWerlag, Vienna, 2008

21. Reich, N., The Principle of Effectiveness and EU Private Law, in: Bernitz, U.; Groussot, X.; Schulyok, F. (eds.), General Principles of EU Law and European Private Law, Wolters Kluwer, 2013

22. Rodríguez, P.M., State Liability for Judicial Acts in European Community Law: The Conceptual Weaknesses of the Functional Approach, The Columbia Journal of European Law, vol. 11, n. 3, 2005, pp. 605-621

23. Scherr, K.M., Comparative Aspects of the Application of the Principle of State Liability for Judicial Breaches, ERA Forum, vol. 12, no. 4, 2012, pp. 565-588

24. Smith, F.; Woods, L., Causation in Francovich: The Neglected Problem, The International and Comparative Law Quarterly, vol. 46, no. 4, 1997, pp. 925-941

25. Steiner, J., From Direct Effects to Francovich: Shifting Means of Enforcement of Community Law, European Law Review, vol. 18, no. 1, 1993, pp. 3-22

26. Tomulić Vehovec, M., The Cause of Member State Liability, European Review of Private Law, vol. 20, no. 3, 2012, pp. 851-880

27. Tridimas, T., The General Principles of EC Law, Oxford University Press, 1999

28. Vaitkevičiūtè, A., Member States Liability in Damages for the Breach of European Union Law - Legal Basis and Conditions for Liability, Jurisprudence, vol. 18, no. 1, 2011, pp. 49-68

29. Valutyte, R., Concept of Court's Fault in State Liability Action for Infringement of European Union Law, Jurisprudencija, vol. 18, no. 1, 2011, pp. 33-48

30. Van Gerven, W., Bridging the Unbridgeable: Community and National Tort Laws after Francovich and Brasserie, International \& Comparative Law Quarterly, vol. 45, no. 3, 1996, pp. 507-544

31. Varga, Z., National Remedies in the Case of Violation of EU Law by Member State Courts, Common Market Law Review, vol. 54, no. 1, 2017, pp. 51-80

32. Varga, Z., Why is the Köbler Principle not applied in Practice, Maastricht Journal of European and Comparative Law, vol. 23, no. 6, 2016, pp. 984-1008

33. Wattel, P.J., Köbler, Cilfit and Welthgrove: We can't go on meeting like this, Common Market Law Review, vol. 41, no. 1, 2004, pp. 177-190

\section{COURT OF JUSTICE OF THE EUROPEAN UNION}

1. Case C-118/08 Transportes Urbanos y Servicios Generales SAL v. Administración del Estado [2010] ECR I-635 
2. Case C-140/97 Walter Rechberger, Renate Greindl, Hermann Hofmeister and Others v. Republik Österreich [1999] ECR I-3499

3. Case C-158/80 Rewe-Handelsgesellschaft Nord mbH and Rewe-Markt Steffen v Hauptzollamt Kiel [1981] ECR 1805

4. Case C-160/14 João Filipe Ferreira da Silva e Brito and Others v. Portugal [2015] ECLI:EU:C:2015:565

5. Case C-160/14 João Filipe Ferreira da Silva e Brito and Others v. Portugal [2015] ECLI: EU:C:2015:390, Opinion of AG Bot

6. Case C-168/15 Milena Tomášová v. Slovakia - Ministerstvo spravodlivosti SR and Pohotovost s.r.o. [2016] ECLI:EU:C:2016:602

7. Case C-168/15 Milena Tomášová v. Slovakia - Ministerstvo spravodlivosti SR and Pohotovost' s.r.o. [2016] ECLI: EU:C:2016:260, Opinion of AG Wahl

8. Case C-173/03 Traghetti del Mediterraneo SpA v. Italy [2006] ECR I-5177

9. Case C-224/01 Gerhard Köblerv Republik Österreich [2003] ECR-I-10239

10. Case C-224/01 Gerhard Köbler v Republik Österreich [2003] ECR-I-10239, Opinion of AG Léger

11. Case C-260/07 Pedro IV Servicios SL v. Total España SA [2009] ECR I-2437

12. Case C-283/81 CILFIT and others v. Ministry of Health and Lanificio di Gavardo SpA v. Ministry of Health [1982] ECR 3415

13. Case C-319/96 Brinkmann Tabakfabriken GmbH v. Skatteministeriet [1998] ECR I-5255

14. Case C-33/76 Rewe-Zentralfinanz eG and Rewe-Zentral AG v. Landwirtschaftskammer für das Saarland [1976] ECR I-1989

15. Case C-352/98 P Laboratoires Pharmaceutiques Bergaderm SA and Jean-Jacques Goupil v Commission [2000] ECR I-5291

16. Case C-392/93 The Queen and H.M. Treasury, ex parte: British Telecommunications [1996] ECR I-1631

17. Case C-429/09 Günter Fußv. Stadt Halle [2010] ECR I-12167

18. Case C-45/76 Comet BVv. Produktschap voor Siergewassen [1976] ECR I-2043

19. Case C-495/03 Intermodal Transports BVv Staatssecretaris van Financiën [2005] ECR I-8151

20. Case C-6/60 Humblet v Belgium [1960] ECR English special edition 559

21. Case C-60/75 Russo v AIMA [1976] ECR 45

22. Case C-620/17 Hochtief Solutions AG Magyarországi Fióktelepe v. Fövárosi Törvényszék [2019] ECLI:EU:C:2019:630

23. Case C-69/14 Dragoș Constantin Târșia v. Statul român and Serviciul Public Comunitar Regim Permise de Conducere si Inmatriculare a Autovehiculelor [2015] ECLI:EU:C:2015:662

24. Joined cases C-447/17 P and C-479/17 P European Union and Guardian Europe Sàrl [2019] ECLI:EU:C:2019:672

25. Joined cases C-46/93 and C-48/93 Brasserie du Pêcheur SA v Bundesrepublik Deutschland and The Queen $v$ Secretary of State for Transport, ex parte: Factortame Ltd and others [1996] ECR I-1029 
26. Joined cases C-6/90 and C-9/90 Francovich and Bonifaci et al. v Italy [1991] ECR I-5357

27. Joined cases C-72/14 and C-197/14 X v. Inspecteur van Rijksbelastingdienst and T.A. van Dijk v. Staatssecretaris van Financiën [2015] ECLI:EU:C:2015:564

\section{ECHR}

1. European Convention for the Protection of Human Rights and Fundamental Freedoms, as amended by Protocols Nos. 11 and 14, 4 November 1950, ETS 5.

2. Judgment Schipani and Others v Italy, Application No. 38369/09

\section{EU LAW}

1. Charter of Fundamental Rights of the European union, OJ C 326, 26 October 2012

2. Recommendations to national courts and tribunals in relation to the initiation of preliminary ruling proceedings, OJ C 380, 8 November 2019

3. Treaty Establishing The European Coal and Steel Community of 18 April 1951

4. Treaty establishing the European Community, OJ C 325, 24.12.2002, p. 33-184 (consolidated version)

5. Treaty on the Functioning of the European Union (TFEU), OJ C 326, 26 October 2012, (consolidated version)

\section{LIST OF NATIONAL REGULATIONS, ACTS AND COURT DECISIONS}

1. Bürgerliches Gesetzbuch, BGBl. I S. 42, 2909; 2003 I S. 738

2. Legge 13 aprile 1988, n. 117., GU 15 aprile 1988, n. 8., as amended by Legge 27 febbraio 2015, n. 18, GU 4 marzo 2015, n. 52

\section{WEBSITE REFERENCES}

1. Cairó Ruiz, E., Joined cases C-72/14 and C-197/14 X and case C-160/14 Ferreira da Silva: is the ECJ reversing its position on the acte clair doctrine?, 23 September 2015, European Law Blog, [https://europeanlawblog.eu/2015/09/23/], accessed 18. March 2020

2. Scherr, K.nM., The Principle of State Liability for Judicial Breaches: The case Gerhard Köbler v. Austria under European Community Law and from a Comparative National Law Perspective, Doctoral Dissertation, European University Institute, 2008, [https://cadmus.eui.eu/ handle/1814/13165], accessed 19. March 2020 